\title{
Utilizarea băuturilor de tip Coca-Cola în patologia gastrică la pacienții pediatrici
}

\author{
Cristina Munteanu
}

Departamentul Pediatrie, Universitatea de Medicină şi Farmacie „Victor Babeş", Timişoara, România

\begin{abstract}
REZUMAT
În faţa tendinţei relativ frecvente a multor persoane - cadre medicale sau nu - de a administra băuturi carbogazoase de tipul Coca-Cola în cazul unor simptome gastrice de tip greaţă sau vărsături la pacienţii pediatrici sau adulţi, am încercat să cercetăm dacă există un fundament ştiinţific la baza acestei practici. Acidul fosforic prezent în această băutură este regăsit în produse care se pot elibera fără prescripţie medicală (OTC), recomandate în stări de greaţă şi vărsături. Pe de altă parte, literatura medicală citează studii în care s-a apelat la acest tip de băuturi în tratarea unor bezoari gastrici sau intestinali, fecaloame sau chiar în unele situaţii de reflux gastric sau gastropareză. Unul dintre studiile analizate relevă efectul antibacterian al acestui tip de băutură pe bacterii precum Bacillus cereus, Enterococcus faecalis, Escherichia coli, Escherichia coli O:157 H:7, Salmonella enteritidis, Yersinia enterocolitica.

Aşteptăm efectuarea mai multor studii privind eficacitatea terapeutică antiemetică şi antimicrobiană a acestei băuturi şi punerea în balanţă a efectelor pozitive versus cele negative în utilizarea sa la copii.
\end{abstract}

Cuvinte cheie: greaţă, vărsături, antiemetic, acid fosforic, Coca-Cola

\section{INTRODUCERE}

Patologia pediatrică - în care ne confruntăm cu simptome de tip greaţă, însoţită sau nu şi de vărsături, meteorism, eructaţii, dureri abdominale, diaree sau constipaţie etc. - este extrem de variată şi cuprinde o paletă largă de afecţiuni, acute sau cronice, cu grad diferit de severitate.

Aceste afecţiuni pot fi din domeniul patologiei gastrice, dar există numeroase alte afecţiuni care la pacientul pediatric pot debuta cu simptome de acest tip. Astfel, aceste simptome le putem întâlni în intoxicaţiile alimentare sau medicamentoase, în diverse intoleranţe şi alergii alimentare, în gastroenteritele de origine virală, boala de reflux gastro-esofagian, hernia hiatală, stenoza hipertrofică de pilor (cu particularitatea debutului după prima - a treia săptămână de viaţă până la 5 luni în cazurile cu debut tardiv) (1), în bolile inflamatorii intestinale, litiaza biliară, pancreatită, apendicită, ocluzie intestinală, migrena abdominală, vărsăturile ciclice etc. Din sfera celorlalte patologii, menţionăm afecţiunile renale, hepatice, neurologice, cele din sfera ORL, parazitare, dezechilibrele metabolice sau endocrine, traumatismele craniene, stresul etc.

În funcţie de etiologia acestor afecţiuni, şi tratamentul va fi diferit (dietetic, medical, chirurgical, psihoterapeutic). Atunci când un copil prezintă stări de greaţă şi de vomă care nu pot fi oprite prin repausul alimentar şi reluarea treptată şi corectă a rehidratării şi alimentaţiei, părintele trebuie să se adreseze unui serviciu medical de urgenţă.

\section{OBIECTIVE}

Obiectivul cercetării de faţă 1 -a constituit identificarea unei legături obiective între consumul băuturilor de tip Coca-Cola şi efectul antiemetic.

Aceasta deoarece există la ora actuală o tendinţă destul de frecventă în populaţia generală de a administra copiilor cu stări de greaţă şi vomă băuturi de tipul Coca-Cola, Pepsi, Fanta, Sprite. Această practică este recomandată chiar de către unele cadre medicale. 


\section{MATERIAL ŞI METODĂ}

Am căutat astfel articole care să facă referire la existenţa unei legături între consumul de băuturi carbogazoase (cu predilecţie cele de tip Coca-Cola) şi efectul lor antiemetic în bazele de date electronice $\mathrm{Pu}$ bmed şi Google Academic în anii 2007-2019.

$\mathrm{Nu}$ am identificat studii legate strict de acest aspect, dar au fost găsite studii privind utilizarea băuturii Coca-Cola în alte patologii gastrice, un studiu care certifică efectul antibacterian al acestui tip de băutură şi un studiu care analizează şi compară osmolaritatea şi conţinutul în electroliţi al băuturilor de tip Cola versus soluţii de rehidratare.

\section{DISCUȚII}

Băutura de tipul Cola stimulează peristaltismul intestinal şi au fost efectuate studii legat de administrarea sa cu efecte pozitive în cazul gastroparezei (2), al bezoarilor gastrici şi intestinali (3-10), al fecaloamelor intestinale (11) şi chiar în refluxul gastro-intestinal (12). De asemenea, unele studii arată că acest tip de băuturi determină creşterea bicarbonatului la nivel gastric şi duodenal, cel mai probabil în legătură cu pH-ul acid al soluţiei (13).

Ne preocupă însă dacă există o legătură între consumul acestei băuturi şi un posibil efect antiemetic. Am continuat astfel cercetările studiind etichetele acestor produse (Coca-Cola, Pepsi-Cola, Sprite, Fanta) pentru a vedea ce declară producătorul ca intrând în compoziţia lor. Nu există un ingredient comun specific pentru aceste produse care să ne poată orienta în demersurile noastre (ingredientele comune tuturor sunt apă, zahăr, dioxid de carbon). Am observat însă un ingredient comun pentru băuturile Coca-Cola şi Pepsi-Cola, acidul fosforic, şi un ingredient comun pentru băuturile Fanta şi Sprite, acidul citric.

Aceste două substanţe - acidul fosforic şi acidul citric - sunt substanţe citate în cărţile de farmacologie cu rol antiemetic, fiind utilizate la prepararea unor limonade (14) efervescente (gazoase) şi negazoase şi fiind recunoscute ca având rol laxativ, purgativ, antiemetic, tonic-revitalizant, recomandat deopotrivă în stările febrile sau în intoxicaţii. Astfel, ediţia a X-a a Farmacopeei Române prezintă reţetele oficinale (15) de limonadă gazoasă pentru soluţia Riviere şi limonadă negazoasă soluţia de citrat de magneziu, cunoscută ca limonada purgativă Roge (16).

Având formula chimică $\mathrm{H}_{3} \mathrm{PO}_{4}$, acidul fosforic apare pe lista aditivilor alimentari ca şi E338 şi este permisă utilizarea sa ca aditiv pentru produsele alimentare consumate de către copii. Acidul citric, având formula chimică $\mathrm{C}_{6} \mathrm{H}_{8} \mathrm{O}_{7}$, apare pe lista anterior men- ţionată ca E330. El este utilizat ca aditiv pentru rolul de potenţiator de aromă sau conservant, inhibând dezvoltarea anumitor microorganisme.

Literatura menţionează recomandarea de administrare în cazul atleţilor care prezintă stări de greaţă, dar nu au vomitat şi nu au febră, a unei soluţii de acid fosforic (17).

Acidul fosforic intră în compoziţia unor medicamente de tip OTC precum Emetrol, Nausetrol, Emecheck, Formula EM, care sunt recomandate în ameliorarea problemelor gastrice, asociate cu greaţă şi vărsături. Toate aceste produse conţin dextroză, fructoză şi acid fosforic.

Un studiu efectuat de un grup de cercetători din Turcia pe trei mărci comerciale de Coca-Cola a relevat un puternic efect antibacterian pe următoarele tipuri de bacterii: Bacillus cereus, Enterococcus faecalis, Escherichia coli, Escherichia coli O:157 H:7, Salmonella enteritidis, Yersinia enterocolitica (18).

Alte cercetări efectuate privitor la administrarea băuturilor de tip Cola în patologiile gastrice cu diaree au urmărit să dovedească dacă această băutură, consumată ca atare sau din care se scoate dioxidul de carbon (,plată“"), poate preveni deshidratarea şi ar putea astfel înlocui soluţiile de rehidratare în cazul copiilor cu pierderi lichidiene (19). Cercetările au luat în calcul valoarea osmolarităţii şi conţinutul în electroliţi al soluţiilor de rehidratare comparativ cu băuturile acidulate de tipul Cola.

În concluzie, putem administra băuturi de tipul Coca-Cola la un copil care vomită?

Este acidul fosforic din această băutură într-o cantitate suficientă pentru a asigura efectul terapeutic antiemetic?

Producătorul nu specifică pe etichetă ce cantitate de acid fosforic conţine băutura. Din cercetările efectuate, am descoperit faptul că băuturile de tipul Cola conţin o cantitate de aproximativ 480-530 mg acid fosforic/l de băutură tip Coca-Cola (20). Cu un calcul simplu, ajungem la o medie de $2,5 \mathrm{mg}$ acid fosforic per $5 \mathrm{ml}$ de băutură tip Cola. Produsele tip OTC ce conţin acid fosforic, utilizate pentru efectul antiemetic, conţin o cantitate mai mare de acid fosforic/5 ml. Astfel, produsul Emetrol conţine 21,5 mg/5 ml, recomadarea de administrare la copii fiind de $5-10 \mathrm{ml}$, cu posibilitatea de repetare după 15 minute de la prima administrare. Rămâne de cercetat dacă putem obţine efectul antiemetic la $2,5 \mathrm{mg} / 5 \mathrm{ml}$, cantitatea medie de acid fosforic per $5 \mathrm{ml}$ băutură tip Cola.

Pe de altă parte, efectul antibacterian al acestei băuturi - dovedit de studiul citat anterior - ar putea sta la baza motivului utilizării acesteia în stările de greaţă şi vărsăturile care au loc în toxiinfecţiile alimentare şi în gastroenterocolitele de diverse etiologii. 
Băuturile de tip Cola au o osmolaritate cuprinsă între $469 \mathrm{mmol} / 1$ şi $656 \mathrm{mmol} / \mathrm{l}$, ceea ce reprezintă o osmolaritate mare comparativ cu cea a soluţiilor de rehidratare avizate de OMS. De asemenea, concentraţia lor în electroliţi este foarte scăzută comparativ cu a soluţiilor de rehidratare. Concluzia studiului analizat a fost că băuturile de tip Cola nu trebuie recomandate ca soluţii de rehidratare în diareea acută, în general, sau în cea la copil, în particular (19).

Trebuie să punem în balanţă şi efectul cafeinei, care va stimula copilul, şi mai ales stimularea gustului pentru dulce şi pentru băuturile carbogazoase, fapt care pe termen lung nu este benefic. Evident, copilul va primi o cantitate mică, câte o linguriţă/înghiţitură; de la o cantitate mică nu ne punem problema de afectare a metabolismului fosfo-calcic sau osteoporoză, eroziuni ale smalţului, dar stimularea gustului pentru astfel de băuturi de la vârstă fragedă poate naște marii consumatori de băuturi carbogazoase de mâine, cu efecte negative pe termen lung.

\section{CONCLUZII}

Tratamentele antiemetice clasice, alopate, au de cele mai multe ori efecte adverse de tipul manifestărilor extrapiramidale şi al reacţiilor alergice, astfel încât apelarea la metode mai puţin tipice sau convenţionale,

\section{BIBLIOGRAFIE}

1. Nelson. Textbook of pediatrics. 18th edition: Saunders Elsevier. 2007:1555.

2. Oberbaum M, Schmell M, Schreiber R et al. "Do two walk together unless they have agreed to do so?" - Combining conventional and complementary medicine in the treatment of gastroparesis. Harefuah. 2015 Jan;154(1):31-4, 68.

3. Ladas SD, Kamberoglou D, Karamanolis $G$ et al. Systematic review: Coca-Cola can effectively dissolve gastric phytobezoars as a first-line treatment. Aliment Pharmacol Ther. 2013 Jan;37(2):169-73.

4. Murrilo-Matamoros $C$, Ferri-Bataller R, Muñiz-Muñoz M et al. Giant gastric phytobezoar secondary to pyloric stenosis treated with Coca-Cola®: A case report. Semergen. 2019 Jan - Feb;45(1):e3-e5.

5. Cerezo Ruiz A, Domíniguez Jiménez JL, Uceda-Vaño. Cellulase, Coca-Cola ${ }^{\circledR}$, pancreatin and ursodeoxycholic acid in the dissolution of gastric bezoars: Why not all together? Rev Esp Enferm Dig. 2018 Jul;110(7):472-473.

6. Yamazato $Y$, Kosuga T, Ichikawa D et al. A Case of Intestinal Obstruction Caused by a Bezoar after Pylous-Preserving Gastrectomy. Gan To Kagaku Ryoho. 2017 Nov;44(12):1269-1271.

7. Endo K, Kakisaka K, Suzuki Y et al. Obstructive Bezoars of the Small Bowel Treated with Coca-Cola Zero through a Long Intestinal Tube and Endoscopic Manipulation. Intern Med. 2017 Nov 15;56(22):30193022.

8. Nelson A, Romo N, Levanon D et al. Gastric Bezoar Treatment Using Oral Coca-Cola. Clin Pediatr (Phila). 2017 May;56(5):485-487.

9. Stathis $P$, Tzias V, Argyris $P$ et al. Gastric bezoar complication of Duodopa $(\circledR)$ therapy in Parkinson's disease, treated with CocaCola(®).Mov Disord. 2014 Jul;29(8):1087-8. care nu ţin de rutina medicală, este un fapt tentant, des întâlnit în populaţia generală. Uneori, practicile sunt inofensive, alteori pot pune în pericol viaţa celor care le testează pe propria piele sau pe a copiilor lor. Deseori, aceste practici sunt încurajate de unele cadre medicale. Astfel stau lucrurile şi cu indicaţia de a administra Coca-Cola copiilor în stările de greaţă şi vomă. Deşi medicina a evoluat, uneori putem apela la metode mai puţin convenţionale cu efect terapeutic dovedit în situaţiile în care se întâmplă să nu avem acces la medic şi medicaţie specifică. În cazul de faţă, am putea beneficia de efectul antiemetic (prin conţinutul în acid fosforic) şi antibacterian al acestui tip de băutură. Recomandarea corectă, principală, din punct de vedere medical este de a merge la medic şi a primi tratament corespunzător, consecutiv identificării cauzei care a generat vărsăturile.

Aşteptăm, astfel, efectuarea unor studii în ce priveşte rolul cert antiemetic al acestor populare băuturi şi extinderea cercetărilor în ce priveşte potenţialul lor antimicrobian şi antiviral în gastroenterocolitele şi virozele intestinale, punerea în balanţă a efectelor pozitive cu cele negative (pe termen scurt şi lung) pentru a putea da un răspuns pertinent asupra acestei probleme şi a siguranţei utilizării băuturilor tip Cola în stările de greaţă şi vărsături la pacienţii pediatrici şi nu numai.

Conflict of interest: none declared Financial support: none declared

10. Lu L, Zhang XF. Gastric Outlet Obstruction-An Unexpected Complication during Coca-Cola Therapy for a Gastric Bezoar: A Case Report and Literature Review. Intern Med. 2016;55(9):1085-9.

11. Ontanilla Clavijo G, León Montañés $R$, Sánchez Torrijos $Y$ et al. Colonic obstruction secondary to sigmoid fecaloma endoscopically resolved with Coca-Cola®. Rev Esp Enferm Dig. 2017 Apr; 109(4):306-308.

12. Gupta E, Hartronft S, Prange M. Coca-cola: A new therapy for reflux. J Am Geriatr Soc. 2009 Feb;57(2):364-5.

13. Sasaki Y, Aihara E, Ise F et al. Stimulatory effect of Coca-Cola on gastroduodenal $\mathrm{HCO} 3-$ secretion in rats. Inflammopharmacology. 2007 Oct;15(5):223-8.

14. https://www.scoalacantemir.ro/files/uploads/Forme_farmaceutice_ca_ sisteme_disperse_omogene.pdf.

15. Farmacopeea Română, ed. a X-a. Bucureşti: Ed. Medicală, 1998:859-860; 867-868.

16. Vicaş LG. Tehnică farmaceutică, Ed. Universităţii din Oradea, 2006:63.

17. Cuppett M, Walsh K. General Medical Conditions in the Athlete. Second edition: Elsevier Mosby, 2012:184.

18. Dağ Ş, Özpinar H, Sari M et al. Antimicrobial Effect of Cola on Several Microorganisms. Cumhuriyet Science Journal. 2015; 36 (1):52-59.

19. M Jacobs, A Reece. Does drinking "flat" cola prevent dehydration in children with acute gastroenteritis? Archives of Disease in Childhood - Education and Practice. 2008;93:129-131.

20. Bello MA, Gustavo González A. Determination of Phosphate in Cola Beverages Using Nonsuppressed Ion Chromatography. Journal of Chemical Education. 1996, 73, 12:1174. 